\title{
Influence of Gandhi on Indian Diaspora in Mauritius (Based on the novel 'Gandhi Ji Bole Thay')
}

\author{
Shaleha Praveen \\ Central University of Himachal Pradesh, Himachal Pradesh, India \\ Corresponding author: shaleha02praveen@gmail.com
}

Received: 03 Feb., 2019

Revised: 07 Apr., 2019

Accepted: 20 May, 2019

\begin{abstract}
Mahatma Gandhi's influence on Mauritius, the impressions of his personality and ideology and his familiarity with the problems of the life of the Indian Diaspora in Mauritius, as well as solving the problems of migrants could be seen during Gandhiji's visit to Mauritius. When the Mahatma visited Mauritius in 1901 he did not get the opportunity to travel extensively in this country because the country was facing an epidemic of plague.. However, he did give the mantras of life, progress and freedom to the Indian immigrants. Mahatma Gandhi, addressing Indian migrant laborers highlighted two basic things; firstly, to educate their children and secondly to participate in the politics of the country; he added that only then the Indian migrants there would be able to get their rights and live in Mauritius. Gandhiji's sharp vision saw what Mauritius needed. He sent Doctor Manilal to Mauritius who strengthened the Arya Samaj and awakened a new consciousness among the Indians. As a result, there was progress in Mauritius and spread of education.

Today, if Mauritius has been so advanced politically and economically education is the main reason of such progress. The famous writer Abhimanyu Anat has depicted Mahatma Gandhi in the novel 'Gandhiji Bole Thay'. The novel 'Gandhiji Bole Thay' reflects basically the socio-economic milieu in which the Indian Diaspora built their fortunes by imbibing the messages given by Gandhiji during his visit to Mauritius. This paper is based on an analysis of this novel.
\end{abstract}

Keywords: Gandhi's basic education, Indian diaspora

Mauritius is one of the most beautiful Islands in the world. Mauritius, which is 1500 miles away from the nearest African coast, is an Island country at a distance of $5110 \mathrm{~km}$ from India. To understand the social, political, economic, cultural and religious characteristics of a country we have to rely on history, The history of Mauritius begins with the immigration of Arabian sailors in 15 century AD when they travelled on 'Dhows' or large traditional sailing vessels with one or more masts. In 1507AD, due to a huge storm in the Indian Ocean Arab sailors had to anchor on Mauritius Island and they named the Island as 'Deen Arobi'. To populate the lonely island, they brought in some people from Arabia which turned out to be a fiasco.
After the Arabs left in a few years, this island was occupied by the Portuguese and they ruled the island for 75 years. After the Portuguese gave up and left the Dutch occupied the island. The Dutch named the island after the Dutch prince, 'MaorisAve-Naso'. The name got corrupted and later came to be called Mauritius. The Dutch tried to develop the island as an agricultural colony, but did not succeed. In 1712, Dutch left the island due to the spread of a 'plague'. After that in 1714, the French established their hegemony over the island and ruled Mauritius for about 95 years. During this period Mauritius was developed by the French. In 1715, they bought the Habsi Slaves from the Madagascar and Africa as their labor force in their fields. 
With the abolition of slavery, Indians came in large numbers. They mostly belonged to eastern Uttar Pradesh and Bihar. The desperate socio economic conditions, total lack of sustainability of agriculture due to floods, droughts and failure of cottage industries resulted in rampant starvation. The British took advantage of such poverty and deprivation and found the starving population to be cheap labor in their colonies like Mauritius, promising them a bright future. Instead of a bright future they found themselves trapped in the island with no way to returnhome. They were treated like the Habsi slaves. Their pathetic condition was a matter of humanitarian concern in Britain leading to strong reactions and protests. "The then Home Minister Lord Glane condemned and said that this is equal to slave tradition" .

But the colonists objected and promised that they would treat the workers humanely. Unfortunately these promises were never fulfilled and remained only in words. Till 1922, the British continued to bring Indians and exploited them. But during this time children of a few Indian indentured Labors got educated. This led to an awakening and consciousness of freedom and a desire to fight against slavery. This is the backdrop of the novel "Gandhi Ji Bole Thay" written by eminent writer Abhimanyu Anat of Mauritius. He pioneered novel writing in Mauritius. He contributed immensely to the promotion of Hindi literature in Mauritius. He graphically described the large scale arrival of Indian indentured labor, their exploitation, repression and the unmitigated sufferings of first generation of those Indians in his novel 'Laal Pasina'. This novel depicts the exploitation of the Indian Diaspora.

In Anat's novel 'Gandhi Ji Bole Thay', the character "Parkash" imbibes the ideology of Gandhiji and sensitively depicts the struggle of the Indian indentured labor in Mauritius. By this time Gandhi as a famous barrister in South Africa had launched the Satyagrah movement for the Indians in South Africa. He was travelling to India from South Africa by sea on board the ship 'Noshera' through Mauritius. The ship developed technical snags and had to anchor in Mauritius on 29 Oct 1901 for repairs. This made Gandhi stay in Mauritius for almost 3 weeks. The committed and enterprising writer, Abhimanyu Anat, had already written about the struggles and sufferings of the Indian workers and emphasized the need for a new awakening and improvement in their condition. He was influenced by the personality and ideology of Gandhi. He writes in the novel 'Gandhi Ji Bole Thay', "I got a letter and came to know that Barrister Gandhi was returning to his country by the ship 'Noshera' after contributing immensely to improve the miserable plight of Indians in South Africa. It is indeed a pleasure if his ship is touching our port. You must send a representative to meet him. He is an incredible person. I am sure that he will definitely meet and help the Indian labors. "

Gandhi's arrival in Mauritius, was indeed a historical occasion which would give a chance to meet him which could help change the condition of Indian indentured labor. Gandhi said that "on arrival of my ship in the port, I lived almost ten days in Mauritius. Only few people knew about me because it was an unscheduled stopover. I stayed at the home of my Muslim friend and I could meet some local people and also met the Governor at a social event."

In South Africa, Gandhi had organized the movement against the discrimination by the white against the black people. Not many among the Indian Diaspora were aware his work in South Africa and so only few people recognized him. That is the reason why only few rich persons were present at Port Luis in the capital of Mauritius to welcome him. But his stay in Mauritius for three weeks was enough for him to understand the Indian workers and their exploitation in the fields and mills of the Sugar industry there.

Unfortunately when Gandhi arrived in Mauritius the island was facing a serious epidemic of Plague, Because of this he could not visit the whole of Mauritius but he understood the conditions of Indian indentured labor. In a speech he illustrated two fundamental principles as advice. Firstly he exhorted people to educate their children and secondly to participate in the politics. This he said would help them get their rights and lead meaningful lives in that country. 
Here is an illustration from 'Gandhi Ji Bole Thay'"My Brothers and Sisters, few of you Indians have some standing in the community. But think of the pitiable condition of your fellow Indians who are laborers. I tell you all, you cannot get your rights if you distance yourself from politics. If you want other people recognize and respect you, then you must be active in politics. A representative of yours must fight to get yours rights in the Legislative Assembly; not from the outside of assembly."

'Madan' a character in the novel 'Gandhi Ji Bole Thay' was highly influenced by this speech of Gandhi and he felt that this was the first time that someone was guiding the indentured laborers of Mauritius to unite.

Gandhi also said, "This is my second request to all of you, I have seen your children and heard their voice. They are intelligent. They need education. You teach your children. They will be the pillars of this nation. In each school space should be available for every child. Education is the only attribute by which your children can stand boldly in front of any person or face any situation."

Inspired by this speech of Gandhi Madan decided that he should send all the children of his colony to school and by the help of his colleague Prem Singh, he enrolled all the children in school.

Education is the core of development. Today, Mauritius is in a good position in the political and economic fields because of education. In Mauritius since 1976, President Shivramgulam ensured that free education was available to all children in the country,

Gandhi did not forget the condition of the Indian Diaspora of Mauritius after he returned to India from Mauritius. Dr Manilal, a member of "Indian Service Society" established by Gopal Krishna Gokhale, was inspired by the Gandhi and reached Mauritius on 11 Oct 1907 and spent the next five years there. During these years he organized many movements for Indian labors and successfully published the first newspaper. Before this there were no writers, reporters, literature, and not even religious preachers. He gave a new life to the Indian Diaspora. It's worth mentioning that Gandhi was the real force to awaken the Indian Diaspora to claim their rights. Madan the character of novel "Gandhi Ji Bole Thay" stands on the "struggle of Parkash" and the "principles of Gandhi". Parkash collects the labors and starts the national movement against the government and owners of sugar mills; this is based on the "principle of non-violence" of Gandhi, and not by violence. Parkash refers to Gandhi's speech before Madan and explained the correct meaning of the "principle of non-violence". Anat says that "Violence is not in my thought and that keeps myself safe. I can't teach the lesson of nonviolence to cowards as I can't show the beauty of forests to a blind person. Nonviolence is the highest form of bravery."

In conclusion it can be said that in the novel "Gandhi Ji Bole Thay" of Abhimanyu Anat mostly the characters were influenced by Gandhi's ideology and to improve the society and their families by making themselves educated and participated in politics. Specially, Parkash and Madan were influenced and were capable to bring the changes in the community of Indian Diaspora. But for Gandhi's visit to Mauritius it was impossible to liberate the Indian workers from their pathetic plight. It also inspired them to claim their rights, understand the actual meaning of life, struggle for it and also for security, dignity, right to education, safety of women and fundamental rights. Abhimanyu Anat drew inspiration from Gandhi's ideology to espouse the demand for fundamental rights of education and politics. The characters in his novel ensured that these were essential for their overall development of which they were the protagonists.

\section{REFERENCES}

Anat, Abhimanyu. 2018. Gaandhi ji Bole The, Rajkamal Prakashan, 205-206.

Anat, Abhimanyu. 2018. Gaandhi ji Bole The, Rajkamal Prakashan, 39.

Anat, Abhimanyu. 2018. Gaandhi ji Bole The, Rajkamal Prakashan, 67.

Pritta, Dr. M.K. 2000. Abhimanyu Anat aur Unke Upanyas: Ek Sanskratik Adhyan, Sarthak prakashan, 23.

Ramsharan, Prahlad. 2017. Mahatma Gandhi aur Mauritius par Unka Prabhaw, Star Publication. 
